\title{
Candeia, o projeto Quilombo e a militância antirracista nos anos 1970
}

\author{
[ Candeia, the Quilombo project and anti-racist activism in the I970s
}

\section{David Treece $^{\mathrm{I}}$}

RESUMO - Ao participar da ressurgência da militância antirracista em meados da década de I970, o Grêmio Recreativo de Arte Negra Escola de Samba Quilombo, fundado pelo compositor e cantor Antônio Candeia Filho, se inspirava no grande exemplo histórico da resistência negra, ou seja, as comunidades de escravos rebeldes chamadas quilombos. Este ensaio reavalia as perspectivas do projeto Quilombo em relação ao antirracismo e à política identitária negra, e mostra como, no auge da ditadura militar, ele propunha uma visão progressista e democrática da resistência enquanto projeto criativo coletivo - tipificado culturalmente pela escola de samba comunitária e pela prática improvisatória colaborativa do samba de partido-alto -, que colocava no centro do seu ideário as tradições estéticas e filosóficas negras, ao passo que atravessava de maneira inclusiva as fronteiras raciais de cor. • PALAVRAS-CHAVE - Samba; antirracismo; quilombo; Candeia; resistência. · ABSTRACT · As it took part in the resurgence of anti-racist activism in the mid I970s, the Quilombo Recreational Guild of Black Art and Samba School, founded by singer-songwriter Antônio Candeia Filho, took its inspiration from the great historical example of black resistance, the rebel slave communities or quilombos. This paper will reassess the Quilombo project's perspectives on the politics of anti-racism and black identity, showing how, at the height of Brazil's military dictatorship, it proposed a progressive, democratic vision of resistance as a creative collective project - typified culturally by the grassroots escola de samba and by the collaborative improvisational practice of samba de partido-alto - which placed black aesthetic and philosophical traditions at its core while inclusively cutting across racial colour lines. . KEYWORDS · Samba; anti-racism; quilombo; Candeia; resistance

Recebido em 9 de novembro de 2017

Aprovado em I2 de julho de 2018

TREECE, David. Candeia, o projeto Quilombo e a militância antirracista nos anos I970. Revista do Instituto de Estudos Brasileiros, Brasil, n. 70, p. I66-I88, ago. 2018.

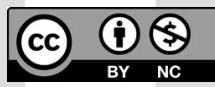

DOI: http://dx.doi.org/Io.II6o6/issn.23I6-90IX.voi7opI66-I88

I King's College London (KCL, Londres, Reino Unido). 


\title{
A música e a nOVa política Negra
}

Se o momento decisivo da história contemporânea da militância negra no Brasil foi certamente a fundação do Movimento Negro Unificado - MNU em I978 (PEREIRA, 20Io, p. 98 e I65)², não é menos verdade que, no âmbito cultural, um de seus componentes mais significativos era o Grêmio Recreativo de Arte Negra Escola de Samba Quilombo (G. R. A. N. E. S. Quilombo), fundado em I975 pelo já respeitado compositor e cantor Candeia (Antônio Candeia Filho).

Em nome do MNU, a jornalista e pesquisadora Lélia Gonzalez foi visitar a sede do Quilombo, em Coelho Neto, para convidar Candeia a contribuir para o evento de inauguração da entidade, que aconteceria em 7 de julho de I978. No entanto, Candeia já sofria de complicações associadas à paralisia da cintura para baixo e, em I6 de novembro, iria falecer de um ataque cardíaco provocado por septicemia. Ele pediu a Lélia que representasse o Quilombo no seu lugar, apresentando-lhe o tema que havia preparado para o carnaval do ano seguinte, com base nas suas leituras de textos clássicos da história e etnografia negras (GONZALEZ, I982, p. 45). O samba-enredo "Noventa anos de abolição", de autoria de Nei Lopes e Wilson Moreira, iria se tornar uma homenagem póstuma a Candeia e às "lutas seculares contra as injustiças raciais" representadas pelos quilombolas:

\author{
Reverenciamos a memória \\ Desses bravos que fizeram nossa história \\ Zumbis, \\ Licutã e Aluma \\ Zundu \\ Loei, Sanin e Dandará \\ E os quilombolas de hoje em dia \\ São candeia que nos alumia. (WILSON MOREIRA; NEI LOPES, I980).
}

Essa última imagem servia para incluir Candeia no rol dos heróis históricos afro-brasileiros, e reconhecia o já emergente perfil quase mítico dele e do projeto

2 Ver também: Hanchard, I994; e Alberto, 20II, p. 29I-294. 
Quilombo como representantes reverenciados e inspiradores de um modelo de resistência negra fundamentada na defesa de práticas culturais populares, comunitárias e historicamente validadas. Contudo, já em I976 a atenção do público se virava para um rival musical potente ao samba como a voz autêntica da identidade afro-brasileira contemporânea: o movimento soul.

Em julho daquele ano a jornalista Lena Frias noticiou no Jornal do Brasil o fenômeno assustador e, para alguns, perturbador dos bailes que tomavam conta dos subúrbios da zona norte carioca, e de outras cidades, atraindo centenas de milhares de negros jovens aos sons do soul e do funk norte-americanos e às suas formas associadas de roupa, estilo e atitude (FRIAS, I976)3. Esses bailes aconteciam muitas vezes nas quadras das escolas de samba, que eram de tamanho suficiente para receberem número elevado de dançantes (THAYER, 2006). Hermano Vianna (I988) calcula que no mínimo cem locais tinham uma capacidade acima de 2.000, e alguns até Io.000, enquanto, na estimativa de Alberto (2009), o total através da cidade chegava a um milhão e meio de participantes.

Muitos jovens negros dentro do movimento organizado eram atraídos também pelo apelo internacional, contemporâneo e aspiracional do fenômeno soul, assinalado pela adoção generalizada da palavra inglesa black assim como utilizada por Frias em Black Rio e bailes black, por exemplo (CONTINS, 2005, p. 54, I24-I3I), o que apontava para uma política cultural moderna, cosmopolita e racialmente mais assertiva, que parecia diametralmente oposta ao tradicionalismo endógeno do samba, ambivalente em relação aos discursos dominantes nacionalistas, às instituições culturais patrocinadas pelo estado e à indústria cultural, principalmente o carnaval. Essa perspectiva levou a críticas intrigantes da viabilidade do samba como expressão eficaz da política do antirracismo e da luta negra no novo contexto, particularmente dentro das fileiras das principais entidades acadêmicas que emergiram no Rio de Janeiro em meados dos anos I970.

Para os africanistas da Sociedade de Intercâmbio Brasil-África (Sinba), por exemplo, as expressões culturais tradicionais afro-brasileiras tais como o samba tinham sido folclorizadas tanto pelo Estado como pela esquerda nacionalista, cooptadas como objetos de consumo e esvaziadas do seu conteúdo político a serviço de um sistema racista (ALBERTO, 20II, p. 262). Os ativistas afiliados ao Instituto de Pesquisa das Culturas Negras (IPCN), no entanto, que acolhiam positivamente o movimento soul, explicavam o apelo dele à juventude como alternativa à força esgotada do, já comercializado, samba:

“Por que esses caras não vão dançar samba?” - perguntariam ainda os idiotas da objetividade. Porque a força contestatória do samba já foi completamente anulada pelas suas próprias instituições. Há muito tempo que as escolas de samba já perderam o rebolado. Ao se transformarem em empresas promotoras de espetáculos para inglês ver, aceitando, inclusive, um vergonhoso contrato de prestação de serviços com a

3 Para relatos mais detalhados do movimento soul brasileiro, ver: McCann, 2002; Alberto, 2009; Sebadelhe; Lima Peixoto, 20I6; Dunn, 2016. 
Riotur, o que restava em termos de "expressão autêntica do povo" foi pra cucuia. (REIS apud ALBERTO, 20I5, p. 85).

Por sua vez, o movimento soul era alvo de críticas, tanto da parte de nacionalistas conservadores, como Gilberto Freyre, que o denunciou como uma tentativa de importar o supostamente alienígena "mito da negritude" para um Brasil fraternalmente mestiço (Jornal do Brasil I7/5/I977 apud OLIVEIRA, 20I4, p. I52), como por nacionalistas de esquerda, como o poeta Ferreira Gullar e o jornalista José Ramos Tinhorão, para quem era um produto imitativo da indústria musical estadunidense. Assim como o samba no início da década de I970, o afro-soul era suscetível também a acusações de cooptação por interesses comerciais, e, se ele oferecia aos jovens negros uma nova forma de autoidentificação, esta ficava contida dentro de um ambiente competitivo e aspiracional de mobilidade social ascensional concedida a alguns pelo ciclo de crescimento pós-I968 conhecido como o "milagre econômico" (RODRIGUES DA SILVA, I983, p. 260-26I). Isso tendia a minar as afirmações dos ativistas do IPCN acerca das suas credenciais politicamente radicais; enquanto o tamanho dos bailes certamente gerava receios junto às autoridades quanto à sua capacidade de mobilizar um movimento racial de massas, o que levou a prisões e interrogatórios de alguns ativistas (ALBERTO, 20II, p. 9-I7), na análise de Bryan McCann o soul era, para a maioria de seus participantes, uma celebração das novas opções culturais oferecidas por um crescente poder de mercado (MCCANN, 2002, p. 50). Num depoimento crítico sobre o movimento, Candeia apontava para seu caráter supostamente burguês ao identificar os donos dos sistemas de som utilizados nos bailes como, na sua maioria, meninos abastados da zona sul 4 .

A rivalidade entre o soul e o samba envolvia portanto uma amálgama complexa de elementos socioeconômicos, culturais e ideológicos. E essa disputa pela lealdade dos participantes jovens negros se realizava num nível local, comunitário, dentro da arena física dos locais e no espaço virtual da mídia. Em 24 de abril de I977, o programa domingueiro Fantástico da TV Globo transmitiu uma matéria sobre o tema "samba de raiz x black music", que exibia cenas de um baile soul que acontecia na quadra lotada da escola de samba Portela. Imagens de cantores e dançarinos elegantemente vestidos e com penteados afro se entrecortavam com entrevistas, juntando os organizadores dos bailes com sambistas respeitados, como Clementina de Jesus, Elton Medeiros e Candeia5. A reportagem terminava com uma interpretação, liderada por Candeia, de "Sou mais o samba", a sua refutação nacionalista do movimento soul e das reivindicações diaspóricas deste:

Eu não sou africano, eu não

Nem norte-americano!

Ao som da viola e pandeiro

Sou mais o samba brasileiro!

[...]

4 Um e Meio, suplemento dominical do Jornal do Comércio, 2I-22 nov. I977 apud Alberto, 20II, p. 26.

5 Para um relato detalhado do relatório, ver: Oliveira, 20I4, p. I5I-I52. 
À juventude de hoje

Dou meu conselho de vez:

Quem não sabe o be-a-bá

Não pode cantar em inglês

Aprenda o português!

$[\ldots]$

Calma, calma, minha gente

pra que tanto bambambam

pois os blacks de hoje em dia

são os sambistas de amanhã!. (CANDEIA, 20I4).

A decisão tomada pelo presidente da Portela, Carlinhos Maracanã, de abrir a sua quadra aos bailes soul foi sem dúvida a gota d'água para Candeia, na sua insatisfação crescente com o rumo que a administração da escola já seguia ${ }^{6}$.

Embora polarizados em interpretações radicalmente divergentes da musicalidade e identidade negras, os sambistas liderados por Candeia e o movimento soul denunciavam uma experiência semelhante de alienação do poder institucional das escolas e dos espaços sociais e culturais que elas controlavam. "Quando a classe média, o branco começou a entrar nas escolas de samba, a gente começou a se sentir um pouco, como se estivesse sendo expulso de lá", explicava um dos principais militantes do MNU, Hamilton Bernardes Cardoso, num documentário da TV Cultura sobre o fenômeno soul, naquele mesmo ano (O NEGRO DA SENZALA AO SOUL..., I977). Agora, porém, as políticas empresariais das escolas davam ao movimento soul a oportunidade de reocuparem fisicamente aqueles mesmos espaços. De importância igual, o movimento contestava a autoridade do samba como uma força política mobilizadora da identidade negra. Como observava o sociólogo Eduardo Oliveira Oliveira no mesmo documentário: "Na reportagem da $\mathrm{Veja}^{7}$ os rapazes dizem que eles aderiram ao soul porque é uma música que empurra pra frente. Então me pergunto: o samba que está sendo feito no Brasil empurra pra frente?”.

Diante de tais perguntas, que duvidavam da capacidade do samba de representar os interesses e as aspirações dos afro-brasileiros contemporâneos, o projeto Quilombo apresenta um caso intrigante, dada a sua reputação duradoura dentro do universo da música popular, assim como no próprio movimento negro. Essa nova reflexão sobre o assunto revisitará os discursos do Quilombo nos seus documentos, nos depoimentos à imprensa e nas suas atividades artísticas, juntamente com os debates contemporâneos, tanto sobre a política antirracista como acerca da evolução da organização do carnaval e das escolas de samba. Reavaliará a produção acadêmica, que já pesquisou exaustivamente a história do projeto Quilombo, mas que não faz justiça a sua contribuição, surpreendentemente rica, ao pensamento do movimento negro em relação a diversas questões: a natureza da luta e da

\footnotetext{
6 Segundo entrevista de 200 I com o ex-membro da Quilombo, morador local e militante negro Deley de Acari apud Buscácio, 2005, p. 88.

7 Referência provável a Black Rio. Veja, 24 nov. I976.
} 
resistência antirracistas, a relação entre raça e classe, entre os conceitos negros e mais amplamente populares de comunidade e coletivismo, as alternativas democráticas ao poder autoritário, e as concepções distintivas de memória cultural, conhecimento, intelectualismo e criatividade.

Uma apreciação melhor dessas intervenções deveria levar-nos a revisar alguns dos pressupostos-chave acerca das perspectivas políticas e culturais do Quilombo. Era, como argumentam os seus críticos, uma espécie de nacionalismo cultural de esquerda, introspectivo, fundamentado numa noção essencializada da "autenticidade" popular e da pureza cultural negra do samba (ALBERTO, 2009) ${ }^{8}$ ? Defender a escola de samba comunitária sob o controle da base artística equivalia a refugiar-se de maneira anacrônica e tradicionalista numa "idade de ouro" idealizada da história do samba, e a negar futilmente a modernização inevitável do carnaval como espetáculo cultural na era do consumismo massificado?

Ao revermos estes argumentos, veremos como, no auge da ditadura militar, a concepção quilombista da identidade negra, como algo plasmado e definido pelas tradições populares comunitárias da história social afro-brasileira, o levou a encarar o espírito repressivo, autoritário e ferozmente capitalista fomentado pelo regime. O resultado foi uma visão progressista e democrática da resistência negro-popular que tinha afinidades estreitas com os princípios fundadores do MNU, como ficaram expostos na Carta de Princípios de I978, e com as ideias de uma de suas fontes intelectuais mais importantes, o quilombismo de Abdias do Nascimento.

\section{SAMBA EM CRISE? AS ESCOLAS DE SAMba ATÉ OS ANOS I970 E O DEBATE SOBRE MODERNIZAÇÃO $X$ TRADIÇÃO}

O impulso para a decisão de criar o G. R. A. N. E. S. Quilombo era a necessidade urgente, na ótica de Candeia, Paulinho da Viola, Monarco (Hildemar Diniz), Wilson Moreira e Elton Medeiros, de uma alternativa àquilo que as principais associações carnavalescas cariocas - e sobretudo a escola de samba do próprio Candeia, a Portela - já se tinham tornado até meados dos anos I970: ou seja, empresas culturais cada vez mais integradas na economia de consumo e no sistema financeiro da cidade do Rio de Janeiro.

Uma dimensão especialmente potente dessa tendência era a incorporação da organização do carnaval carioca no interior da indústria turística do estado. Em novembro de I975, a Associação de Escolas de Samba assinou um acordo com a Riotur, a empresa municipal de turismo que foi fundada em I972. Como uma manchete de jornal resumia francamente - "Samba é vendido ao turismo oficial" (SWAN, I975) -, o contrato substituiu os subsídios estatais às escolas por uma porcentagem dos ingressos para os desfiles, e adicionou uma cláusula de exclusividade que as obrigava a participar no calendário oficial de atividades turísticas, enquanto as proibia de aparecer livremente nas ruas sem a autorização e a participação da Riotur. O presidente da empresa, Vitor Pinheiro, resumia a pauta assim: "As escolas de samba perderam criatividade em sua evolução, mas ganharam dimensão maior em termos comerciais. Por isso pretende [sic]

8 Ver também: Fernandes, 20I4. 
explorar comercialmente apresentações em clubes, estações de televisão, festas e outras exibições no Rio, no Estado e no exterior" (apud OLIVEIRA, 20I4, p. 48-49).

O projeto Quilombo, que foi inaugurado poucas semanas depois da assinatura do contrato da Riotur, representava uma crítica de cada aspecto das escolas de samba contemporâneas: não apenas o caráter "grande capital" da sua organização econômica, mas também a estrutura vertical da sua administração política, a estética grandioso-espetacular do desenho artístico, e seu afastamento das raízes populares da tradição do samba e daquilo que significava como expressão da resistência negra. O novo projeto, em contrapartida, foi concebido lembrando "os tempos heroicos da Portela, do Salgueiro, tempos comunitários, a escola dirigida pelos próprios sambistas, sem paternalismos de bicheiros, de políticos. Lembrados os nomes de sambistas descontentes, dos que abandonaram a Avenida ao vê-la reservada aos turistas" (BARROSO apud BUSCÁCIO, 2005, p. 7I). Portanto, os objetivos centrais do Quilombo, segundo Candeia, eram:

I. Desenvolver um centro de pesquisas de arte negra, enfatizando sua contribuição à formação da cultura brasileira.

2. Lutar pela preservação das tradições fundamentais sem as quais não se pode desenvolver qualquer atividade criativa popular.

3. Afastar elementos inescrupulosos que, em nome do desenvolvimento intelectual, apropriam-se de heranças alheias, deturpando a pura expressão das escolas de samba, e as transformam em rentáveis peças folclóricas.

4. Atrair os verdadeiros representantes e estudiosos da cultura brasileira, destacando a importância do elemento negro no seu contexto [...]. (CANDEIA apud RANULPHO, I976).

Porém, Candeia e seus colegas não eram de longe os primeiros artistas a manifestarem tais preocupações; estas remontam no mínimo ao início dos anos I960, quando figuras de renome como Ismael Silva e Cartola já criticavam as escolas lendárias que tinham ajudado a fundar na década de I920 (Estácio e Mangueira, respectivamente) por abandonarem o espírito tradicional da festividade popular em favor dos espetáculos extravagantes dominados por interesses comerciais (RODRIGUES, I984, p. IO9 apud FERNANDES, 20I4, p. I4I). Em I962, sob a liderança do etnógrafo Edson Carneiro, o Primeiro Congresso Nacional do Samba reuniu um grupo formidável de músicos, intelectuais e jornalistas para debater essas mudanças no caráter das escolas (MOTTA FARIA, 20I3, p. 3). As recomendações coletivas do Congresso para a proteção da "essência cultural" do samba frente à pauta modernizadora ficaram registradas numa "Carta do Samba", cuja data, 2 de dezembro, passou a ser o Dia Nacional do Samba (MOTTA FARIA, 20I3, p. 2-3). De fato, I962 foi percebido como o ano decisivo quando o carnaval "se comercializou", com as primeiras vendas de ingressos e a construção das arquibancadas (MOTTA FARIA, 2013, p. 6). A imprensa desempenhou um papel importante na causa tradicionalista a partir desse momento, quando alguns jornais patrocinaram concursos de samba, e jornalistas como Sérgio Cabral, Roberto Moura e José Ramos Tinhorão, que iriam publicar estudos importantes da história do samba e do carnaval no contexto da 
indústria cultural (CABRAL, I996; MOURA, 2004; TINHORÃO, I966, entre outros), alertaram para a expansão dos desfiles, o "embranquecimento" do perfil de seus participantes, e o interesse crescente das emissoras, da mídia internacional e do setor turístico (MOTTA FARIA, 20I3, p. 6).

Estas eram mais do que meras preocupações alarmistas. Transformações reais e profundas de ordem social, econômica e estética já começavam a atingir o formato e a organização dos desfiles, incluindo restrições punitivas à duração permitida para cada escola e a imposição pelas emissoras de um regime mais rigoroso de programação; a cobrança de ingressos pagos; a expansão da base social das escolas para acomodar os turistas e os moradores de classe média da zona sul; o registro de direitos autorais para a composição dos sambas-enredo, o que obrigou as escolas a se adaptarem às exigências comerciais da indústria fonográfica, e, mais controvertida ainda, a influência crescente de uma nova categoria de figurinistas, coreógrafos e cenógrafos profissionalizados, muitas vezes de formação universitária - os carnavalescos - sobre a conceituação e a execução de cada desfile (CUNHA, 2009, p. 29). O mais exemplar dos carnavalescos era Fernando Pamplona, que, por seu trabalho com o G. R. E. S. Acadêmicos do Salgueiro, de I960 em adiante, mereceu o crédito de ter introduzido a nova estética e, para alguns críticos, de ter levado ao "embranquecimento" do samba como mercadoria massificada de consumo (MONTE, I996-I997, p. 22). Como veremos, uma dimensão importante da pauta do Quilombo era a defesa do papel dos sambistas, dos intérpretes-compositores, diante do controle artístico cada vez mais usurpador exercido pelos carnavalescos sobre o trabalho das escolas.

É interessante notar que, além das inovações estéticas daqueles anos, o Salgueiro, sob a orientação de Pamplona, foi pioneiro também em efetuar uma virada radical de ordem temática nos desfiles. No mesmo período em que Candeia começava a abandonar a tendência ufanista-nacional do início da carreira para tornar-se defensor do orgulho negro (VARGENS, I997, p. 29-35), por exemplo, em "Dia de graça" (I969), a escola investia numa série de enredos baseados em tópicos afro-brasileiros: Quilombo dos Palmares (I960), Chica da Silva (I963), Chico-Rei (I964), Bahia de Todos os Deuses (I969) e Festa para um Rei Negro (Pega no ganzê) (I97I) (VIVEIROS DE CASTRO, I999, p. 32). Mas havia muito mais em jogo do que essa virada temática para a história e identidade negras. Uma coisa era celebrar os heróis da resistência afro-brasileira, mas isso por si só não alterava as condições e as estruturas do poder que cercavam a interpretação e a representação da identidade negra; também não enfrentava o lugar da agência criativa ou da propriedade artística dentro da política cultural do carnaval e das suas organizações, e não resolvia por si só as contradições entre nação e raça, ou a compulsão do discurso nacionalista de assimilar a diferença negra como "patrimônio".

Tais questões de poder e agência costumam ser facilmente ofuscadas por uma tendência a dicotomizar o argumento como se se tratasse simplesmente de um conflito entre "modernizadores" e "tradicionalistas". Sem dúvida, a intervenção

9 Num ensaio recente, Stephen Bocskay (2017, p. 70) se refere à categorização frequente de Candeia como um "samba preservationist" ("preservacionista do samba"), porém ele mesmo insiste nesse termo. 
de Candeia acontecia no contexto de uma disputa mais ampla pela legitimação de determinada "tradição" musical, supostamente mais autêntica - denominada "samba de raiz" - que, como já vimos, foi levada à esfera pública na década anterior pelo Primeiro Congresso Nacional do Samba. Porém, se Candeia iria certamente retomar uma época "áurea" na história da Portela em busca de um modelo alternativo para a escola de samba, o conceito de "raiz" iria muito além de mero preservacionismo ideológico ou estético. Myrian Sepúlveda dos Santos nos lembra que no universo dos sambistas tais debates ocorrem, não num vazio abstrato, mas dentro de um campo contestado, estruturado por relações objetivas de poder social e cultural (SEPÚLVEDA DOS SANTOS, I998, p. I23). E nesse caso, como esclarecem Felipe Trotta e João Paulo M. Castro, quando se fala da "perda da tradição", o que está em disputa é mais um sentido de propriedade coletiva, um domínio artístico "nosso" dos meios de produção, poderíamos dizer, do fazer cultural (TROTTA; CASTRO, 200I, p. 64-67).

O projeto Quilombo e a sua criação eram o resultado de uma luta pelo poder que colocou Candeia e seus companheiros artistas em conflito com a direção da Portela. Estava em jogo não apenas uma contradição entre diversas culturas políticas - autoritária e democrática - mas o próprio papel dos sambistas na economia criativa da escola, a autonomia artística dos compositores diante das exigências da indústria fonográfica e das transformações no formato estético dos desfiles, e a relação entre a identidade cultural negra e as tradições populares coletivas de invenção musical, tais como o samba de partido-alto.

\section{Candeia e a ruptura com a Portela: mercados, MODERNIZADORES, SAMBISTAS E CARNAVALESCOS}

Após iniciar a sua participação da Portela já na adolescência, na década de I950, Candeia entrou na carreira de policial, que foi interrompida traumaticamente em dezembro de I965 quando, num incidente de trânsito, ele levou cinco tiros, deixando-o paralisado da cintura para baixo e confinado permanentemente a uma cadeira de rodas. Parece evidente que a sua recuperação física e espiritual durante os anos seguintes se deveu muito a seu comprometimento com a Portela e com o universo do samba. Já nos finais da década ele se dedicava de novo à causa em tempo integral, promovendo pagodes regulares na sua casa e dando provas de liderança pelo seu trabalho para o setor cultural da escola (CUNHA, 2009, p. 27-28). Assim o vínculo entre o samba e o conceito da resistência, que iria ser um baluarte do projeto Quilombo, ficou consolidado para ele no âmbito pessoal, existencial, como se encontra registrado expressivamente na composição "De qualquer maneira", de I97I:

De qualquer maneira

Meu amor eu canto

De qualquer maneira

Meu encanto, eu vou sambar

$[\ldots]$ 


\author{
Sentado em trono de rei \\ Ou aqui nesta cadeira \\ Eu já disse, já falei \\ Que seja qual for a maneira \\ Quem é bamba não bambeia \\ Falo por convicção \\ Enquanto houver samba na veia \\ Empunharei meu violão. (CANDEIA, 20I4) ${ }^{\text {Io }}$.
}

Mas nesse intervalo já começavam a despontar os atritos entre a direção administrativa da Portela e a composição artística da escola, sobretudo a Velha Guarda. Um esteio da Velha Guarda, Monarco, descrevia a "decadência" que já ocorria sob a presidência de Nelson Andrade (I962-I966), e que agora provocou a saída dos também veteranos Manaceia e Alvaiade:

Ele era do Salgueiro e foi para a Portela, seu Natal convidou ele. Chegou lá, não conhecia nada de samba, começou a falar em valores novos, que a Portela só tinha velharia. $\mathrm{O}$ Nelson Andrade começou a mudar a estrutura da Portela, inventando moda. A Portela ganhou alguns carnavais que foram taxados de "ganhados-nos-dedos" que significa ganhar ilicitamente. E a Portela nunca teve necessidade disso, porque ela descia pra valer, com grandes poderes, grandes sambistas e muita moral. (NEWLANDS, I986, p. II9).

O aliado de Andrade, e o financiador das reformas modernizadoras da próxima década, era Natal (Natalino José do Nascimento), um bicheiro cujos lucros ajudaram a construir a nova sede da escola, o Portelão, em I972. No mesmo ano Natal indicou um sócio íntimo, também bicheiro, Carlinhos Maracanã (Carlos Teixeira Martins) à vaga da presidência, que ele ocuparia pelos 32 anos seguintes (BUSCÁCIO, 2005, p. III; CABRAL, I996, p. I98). O outro nome-chave que integrou a nova "liderança forte" da Portela foi o carnavalesco Hiram Araújo, cujo controle do departamento cultural logo alienou os sambistas representados por Candeia e Paulinho da Viola. Um episódio notório de 1972 ilustra a conduta autoritária de Maracanã, a quem Candeia iria depois denunciar como "fascista". Num concurso de samba de terreiro, organizado por Candeia, Paulinho da Viola e Carlos Elias, Maracanã impôs o candidato dele, David Corrêa, que nem era membro da ala dos compositores e já tinha sido desclassificado numa rodada anterior. $\mathrm{O}$ desrespeito grosseiro pelo valor tradicional do cargo artístico a favor de estranhos nomeados de cima e sem formação popular provocou o desgosto dos veteranos Carlos Elias e Zé Kéti, que se afastaram logo da escola; Candeia permaneceu ainda, acreditando que era melhor batalhar por dentro, mas apenas até o carnaval de I975, quando a Portela foi relegada ao quinto lugar (BUSCÁCIO, 2005, p. II4). Foi assim que ele avaliou o incidente, a intervenção dos sambistas veteranos e a sua derrota: 
[...] aquele movimento foi de uma importância fundamental dentro da escola, sabe por quê? Porque ali nós já estávamos sentindo a necessidade de soerguer coisas que estavam se extinguindo. Então, nós fizemos aquele concurso, mas mantendo as diversas características, quer dizer, o samba de terreiro e o partido-alto, exatamente para incentivar o pessoal a voltar a compor e cantar samba de terreiro e partido-alto. Mas o que fizeram esses inovadores? Mataram tudo isso, jogaram por terra. (RABELLO apud CUNHA, 2009, p. 38).

Isso era bem mais do que uma guerra territorial pelo controle organizacional; e embora possamos sentir, na pauta democrático-popular da base artística, as reverberações das lutas mais amplas entre os movimentos sociais emergentes e a ditadura sob o mandato Geisel, era mais do que isso também. Os sambistas e os carnavalescos ocupavam posições e visões concorrentes dentro da economia criativa da escola, aqueles com um estilo de vida e uma visão de mundo formados por identificações e filiações comunitárias - ou seja, ao morro, à escola de samba, e às suas expressões artísticas e aos seus antecedentes históricos - o samba de terreiro, o samba de partido-alto, o jongo, o samba de roda e o candomblé, ao passo que os carnavalescos mediavam as demandas econômicas e culturais do mundo "fora" da comunidade: o turismo, os consumidores de classe média da zona sul, e a indústria fonográfica (VIVEIROS DE CASTRO CAVALCANTI, 2006, cap. 2 e 3).

O sintoma mais marcante dessas forças externas de mercado talvez seja o impacto que elas exerceram sobre o trabalho dos sambistas e sobre a estética formal da composição. À medida que os ensaios davam lugar a bailes carnavalescos, como lembra Paulinho da Viola, os compositores se sentiam pressionados a ajustarem o compasso das músicas "para criar um clima de embalo, com aqueles refrões em lá, lá, laiá etc. O samba perdeu aquela cadência gostosa, aquela harmonização. É muito fácil comparar os sambas atuais e antigos das escolas: hoje o samba ficou banal e menor"Ir. Foi dado ao samba-enredo da Salgueiro, "Festa para um rei negro" de I97I, conhecido melhor como "Pega no ganzê", o crédito de ter iniciado a tendência a abandonar o tipo "lençol", que data dos anos I950 - ou seja, um samba "grande" feito de narrativas extensas de 40 ou mais versos que "cobriam" todo o enredo - substituindo-o por uma forma mais acelerada, estilo marchinha, com uma letra mais curta que visava a comunicação fácil com o público (MOTTA FARIA, 20I3, p. 9; TINHORÃO, I975, p. I83).

Essa tendência foi redobrada pela incorporação dramaticamente rápida dos sambas-enredo no interior do setor fonográfico comercial, justamente no período em que se consolidava o mercado de bens simbólicos e, dentro dele, a indústria fonográfica brasileira, com índices de crescimento médio na venda de discos de até 400\% entre I965 e I972 (TOSTA DIAS, 2000, p. 5I-65). Em I972, a Associação das Escolas de Samba assinou um contrato com a gravadora Top Tape, que, em I968, fora a primeira a vender registros dos desfiles gravados ao vivo (BUSCÁCIO, 2005, p. I29-I30). Durante alguns anos a partir de I973 esses LPs estavam entre os mais vendidos no Brasil, sendo I975 o ano de maior expansão para o perfil mercadológico e midiático do samba. Porém, essa exposição comercial custou caro, porque duas

II Entrevista com Ruy Fabiano, Jornal de Música, apud Oliveira, 20I4, p. 52. 
gravadoras rivais, a Top Tape e a Tapecar, já começaram a apertar o controle sobre os compositores em conjunto com as escolas. Na esteira do carnaval de I975, o jornal Última Hora noticiou que os "compositores são coagidos pelas escolas de samba a gravar na Tapecar. Se escolherem outro selo para gravarem, ficam (sic) fora da escolha do samba". Em outubro desse ano, a Top Tape assinou um novo contrato exclusivo com a Associação, antecipando vendas de no mínimo 300.000 para o carnaval do ano seguinte (OLIVEIRA, 20I4, p. 49-50). Um dos produtos do processo de filtragem dos estúdios era o "sambão" "um estilo de samba melodioso, com letras picantes ou românticas, de ritmo cadenciado, mas sem os timbres 'sujos' ou em estado bruto que caracterizavam os sambas 'de morro'” (NAPOLITANO, 200I, p. 339-340).

Candeia permanecia em discordância com essa tendência nas suas gravações durante o mesmo período - o que se nota, ao contrário, é um perfil cada vez mais marcado pela concentração nas tradições afro-brasileiras, até chegar no LP Samba de roda (I975), que ao lado de sambas de roda incluía motivos adaptados da capoeira, do maculelê e do candomblé, e os três álbuns colaborativos de Partido em 5 (I972-I975), dedicados inteiramente ao partido-alto - e que buscavam propositadamente uma espontaneidade tosca, lembrando as rodas de samba de botequim ou de quintal (BUSCÁCIO, 2005, p. 50). Quanto à disputa pela seleção do samba-enredo da Portela, Candeia já se considerava como intruso em termos dos recursos econômicos necessários para exercer qualquer influência; sem uma torcida organizada, paga e transportada por encomenda da comunidade, ele argumentava, seria impossível quebrar o boicote institucional que a escola já impunha: “É, tem que investir nisso tudo, pra poder competir dentro da escola, com a minha torcida, aquela facção, se não eu vou pegar no microfone, vou cantar sozinho, ninguém vai cantar comigo"ז2.

Esse era o contexto quando, em março de I975, junto com André Motta Lima, Carlos Sabóia Monte, Claudio Pinheiro e Paulo Cesar Batista de Faria, Candeia entregou um documento de 3.000 palavras ao presidente da Portela, propondo uma série de reformas que possibilitasse à escola recuperar seu merecido lugar histórico de liderança no universo do samba e da cultura popular. A premissa de abertura da proposta era que, fiel a suas origens, uma escola de samba deveria representar "a manifestação mais autêntica" do povo, e que quanto mais caísse sob a influência externa de indivíduos não integrados na sua vida quotidiana, mais deturpada, imitativa e não representativa iria se tornar. Muitas das suas recomendações, portanto, visavam melhorar a coerência orgânica entre a composição comunitária da escola, sua direção administrativa e seus carnavalescos profissionalizados, fundamentada no respeito mútuo e no investimento na formação de figurinistas e cenógrafos no interior da entidade, enquanto a política expansionista do recrutamento externo deveria cessar.

Ao mesmo tempo, um fio insistente do documento reivindicava a liberdade criativa para os compositores e para a comissão de carnaval. A tendência a adotar o samba-enredo mais curto deveria ser contida, enquanto se recomendavam concursos e festivais para promover outras tradições comunitárias como o samba de

I2 Entrevista com João Bosco Rabello em "Escola de samba, cultura popular". Correio Braziliense, Suplemento Especial, 22 jan I978, apud Buscácio, 2005, p. I30. 
terreiro e o samba de partido-alto. A postura dos dissidentes com respeito à questão conservadora/modernizadora ia além de um mero preservacionismo defensivo, e se resumia da seguinte forma: "A Portela precisa assumir posição em defesa do samba autêntico. Isso não significa um retorno à década de I930, mas uma posição de autonomia e grandeza suficientes para só aceitar as evoluções coerentes com o engrandecimento da cultura popular" (VARGENS, I997, p. 67-72).

Contudo, essas propostas cuidadosamente elaboradas nem foram debatidas pela direção da Portela e, por consequência, atendendo à sugestão de seu cunhado, Candeia passou a estabelecer um bloco independente num terreno baldio no bairro de Rocha Miranda, levando o nome do quilombo mais célebre, o histórico Palmares. Em 8 de dezembro de 1975 foi inaugurado como plena escola o Grêmio Recreativo de Arte Negra Escola de Samba Quilombo, transferido em janeiro de I976 para Coelho Neto, mantendo ininterruptas as suas atividades até I98I.

\section{O PROJETO QUILOMBO: INTELECTUAIS POPULARES, TRADIÇÃO COMUNITÁRIA E CRIATIVIDADE NEGRA}

Junto com Candeia, como primeiro presidente do conselho deliberativo do Quilombo, se reuniam os seguintes nomes: o fundador da Velha Guarda da Portela, Paulinho da Viola, e o veterano Monarco, que era membro da ala dos compositores desde os anos I950; os compositores Wilson Moreira (que veio da Mocidade Independente do Padre Miguel para se juntar à Portela em I968), Elton Medeiros (que conheceu Paulinho da Viola no Zicartola e tocou com ele na banda Os Cinco Crioulos de I967 a I969), e Rubem Confete (Rubem dos Santos), que era também jornalista e cofundador em I976 do IPCN; os jornalistas Juarez Barroso, Dulce Alves e Lena (Marlene Ferreira) Frias, autora das reportagens "Black Rio", de I976 (ALBERTO, 2009, p. I7-22), e por último o ator e militante Jorge Coutinho, no cargo das relações-públicas.

A composição nuclear de liderança da nova entidade era bastante reveladora de sua visão política, já que efetivamente ela trocava o triunvirato endinheirado e autoritário da Portela por um agrupamento amplo de artistas e ativistas que se originavam não apenas da própria Portela mas de diversos grupos de interesse também. A aderência ao Quilombo não pretendia substituir a afiliação às escolas existentes, em vez disso ela procurava criar um "espaço simbólico, criativo", que congregasse os sambistas da cidade inteira (CUNHA, 2009, p. 50). Com efeito, a lista dos signatários ao manifesto do Quilombo constituía um conjunto daqueles que poderíamos chamar intelectuais populares, em contraposição às conotações negativas do termo "intelectual", assim como era utilizado por Candeia para referir-se criticamente aos carnavalescos universitários, considerados alheios ao comprometimento com "os valores afro-brasileiros" e com a cultura popular (CANDEIA; ISNARD, I978, p. 68-69). Na verdade, como nos lembra Buscácio (2005, p. I9), os jornalistas, os professores universitários, os produtores culturais e outros formadores de opinião desempenharam um papel importante na criação do Quilombo. E suas atividades iriam incluir muitas que merecem ser chamadas "intelectuais": 
A Quilombo, em sua sede, conseguiu agrupar cerca de duzentas pessoas cada noite, para participar de conferências sobre assuntos de suma importância para o estudo da contribuição negra na formação cultural do Brasil. É bom frisar que na ocasião não havia comida e muito menos samba, e que a maioria dos presentes era composta de residentes do morro do Jorge Turco e da favela de Acari. Prestaram sua colaboração, entre outros, os seguintes estudiosos: Prof. Antônio Carlos Ferrão (“Contribuições do negro no desenvolvimento do Brasil”), Profa. Beatriz Nascimento ("Zumbi, rei do estado de Palmares?”), Profa. Ricardina (“A posição da arte negra”) e Prof. Eduardo de Oliveira e Oliveira (“Ganhos do negro no mundo”). (VARGENS, I978 apud BUSCÁCIO, 2005, p. 23).

A questão, no entanto, é que os estudiosos desse perfil pertenciam à primeira geração de negros intelectuais a ganharem acesso à universidade e a conseguirem cargos docentes em número significativo (a nomeação de afro-brasileiros a tais cargos sendo quase nula até finais dos anos I970) (SANTOS, 20II), e que seu comprometimento com a causa do samba, junto com os próprios sambistas, era como ativistas enraizados na comunidade e que se identificavam com as suas condições e seus interesses materiais, em vez de agirem num espaço puramente intelectual; algo próximo, portanto, ao conceito gramsciano do "intelectual orgânico" (CAMMETT, I967, p. 202).

Além dos indivíduos já mencionados, Candeia contou com o apoio de outros dois intelectuais populares para articular os princípios e objetivos do Quilombo em textos escritos. João Baptista Vargens, que em I982 seria selecionado pela Fundação Nacional de Artes (Funarte) para escrever a biografia de Candeia, tinha passado a adolescência em Oswaldo Cruz, próximo aos bambas da Velha Guarda da Portela, antes de se formar em Ciências Humanas na UFRJ (VARGENS, I997). No Manifesto do Quilombo, o documento fundador da entidade, Vargens recorreu a uma linguagem lírica e visionária para falar em nome do movimento na voz da inspiração popular:

Estou chegando...

Venho com fé. Respeito mitos e tradições. Trago um canto negro. Busco a liberdade. Não admito moldes.

As forças contrárias são muitas. Não faz mal... Meus pés estão no chão. Tenho certeza da vitória.

Minhas portas são abertas. Entre com cuidado. Aqui, todos podem colaborar. Ninguém pode imperar.

Teorias, deixo de lado. Dou vazão à riqueza de um modo ideal. A sabedoria é meu sustentáculo.

O amor é meu princípio.

A imaginação é minha bandeira.

Não sou radical. Pretendo, apenas, salvaguardar o que resta de uma cultura. Gritarei bem alto explicando um sistema que cala vozes importantes e permite que outras totalmente alheias falem quando bem entendem. Sou franco-atirador. Não almejo glórias. Faço questão de não virar academia. Tampouco palácio. Não atribua a meu nome o desgastado sufixo -ão. Nada de forjadas e malfeitas especulações 
literárias. Deixo os complexos temas à observação dos verdadeiros intelectuais. Eu sou povo. Basta de complicações. Extraio o belo das coisas simples que me seduzem. Quero sair pelas ruas dos subúrbios com minhas baianas rendadas sambando sem parar. Com minha comissão de frente digna de respeito. Intimamente ligado às minhas origens.

Artistas plásticos, figurinistas, coreógrafos, departamentos culturais, profissionais: não me incomodem, por favor.

Sintetizo um mundo mágico.

Estou chegando... (VARGENS, I997, p. 66).

Ou seja, o Quilombo defendia um espírito libertário, antielitista e anti-institucional de autonomia cultural e inclusividade democrática, um tradicionalismo enraizado nas práticas comunitárias. No samba "Nova escola” (I977), Candeia interpretava musicalmente esses mesmos princípios:

Da manhã quero os raios do sol

Quero a luz que ilumina e conduz

A magia e a fascinação

Voa um poeta nas asas da imaginação

A arte é livre e aberta, a imagem do ser criador

Samba é verdade do povo

Ninguém vai deturpar seu valor

Canto de novo

Canto com os pés no chão

Com coração canta meu povo

Meu samba é bem melhor assim

Ao som deste pandeiro

E do meu tamborim

As cores da nossa bandeira

Traz o branco inspirado

Na simplicidade da paz

Sintetiza um mundo

De amor e nada mais

Simbolizado no dourado e no lilás. (CANDEIA, I977).

O depoimento inaugural de Vargens foi complementado pela publicação, em I978, de Escola de samba: árvore que esqueceu a raiz, de coautoria de Candeia e Isnard Araújo, que tinha sido responsável no início da década pela criação do projeto do Museu Histórico Portelense (BUSCÁCIO, 2005, p. 97). O livro pode se considerar sucessor desse projeto, ao dedicar-se à reabilitação do legado das agremiações carnavalescas, exemplificado pela evolução histórica da Portela, anterior à sua transformação recente. Porém, o conteúdo informativo dessa narrativa e sua crítica à pauta modernizadora deixam patente o argumento, já bem mais contundente, acerca do imperativo político da resistência enquanto questão de consciência de raça 
e classe. Longe de ser um simples antimodernismo "preservacionista", a crítica ao modelo industrial das escolas agora se tornava uma defesa explícita da identidade negro-popular, que vinculava as lutas anticapitalistas e democráticas à história da resistência negra desde a era da escravidão:

Para se falar em SAMBA temos que falar em negro, para se falar em negro temos que contar sua árdua luta através de muitas gerações, erguendo o seu grito contra o preconceito de raça e cor, herança da escravidão. O negro, com sua luta, vem de muito longe, dos Quilombos e das insurreições de escravos. Se voltarmos para a história nacional, encontraremos sua presença em todos os setores de nossa vida social. (CANDEIA; ISNARD, I978, p. 4-5).

Com efeito, o livro de Candeia e Isnard inclui uma parte especial, “O Negro”, cujo prefácio reproduz em português a afirmação famosa do escritor James Baldwin acerca da condição negra nos Estados Unidos: "Ser um negro neste país e ser relativamente consciente, é estar em fúria quase todo o tempo" (BALDWIN, I96I, p. 205). Nesse mesmo espírito, ao denunciarem o legado do racismo estrutural, que mantém o afro-brasileiro "domesticado" e marginalizado do sistema de ensino, da vida profissional e da participação política, Candeia e Isnard convocam o negro brasileiro a criar instrumentos de pressão e ação direta, nos interesses da sociedade como um todo, "isento de ódio ou ressentimento, porém, firme e inarredável do justo lugar a que tem direito [...] Não temam 'pecha' de racista negro, pois é outra tática de intimidação e de imobilização. Basta-nos a integridade de nossa consciência de democratas e de humanistas" (CANDEIA; ISNARD, I978, p. 84-85). Aliás, em I976, Candeia e Elton Medeiros já tinham enfrentado na imprensa a acusação de "racismo negro", argumentando que o Quilombo era um movimento de resistência, não contra os muitos brasileiros brancos que já engrossavam as fileiras das escolas de samba, mas contra a erosão da identidade das escolas pelos “inovadores”, não importava a sua cor ou origem. A discriminação era alheia a seu espírito inclusivo, que celebrava a contribuição, tanto dos sambistas brancos como dos negros, às suas tradições criativas (VARGENS, I997, p. 75).

Esta afirmação antissectária é decisiva para entendermos como o Quilombo articulava a relação entre militância cultural afro-brasileira, raça e classe. A insistência de Candeia em enraizar o movimento contemporâneo pela resistência cultural na história e nas tradições negras não equivalia simplesmente a essencializar o samba enquanto "música negra"ז3 nem tampouco ela se traduzia facilmente numa política separatista do nacionalismo negro, nem numa versão negra da brasilidade musical ${ }^{\mathrm{I} 4}$. Melhor, ela argumentava que os impulsos criativos fundamentais do samba estão profundamente vinculados à luta dos negros brasileiros e das massas mais amplas do povo brasileiro por resgatarem a cidadania e a agência que lhes foram negadas pelas narrativas dominantes da construção nacional. Assim, como o objetivo prático do Quilombo era organizar uma escola que servisse "de teto a todos

I3 Como afirma Fernandes em: Fernandes, 20I4.

I4 A formulação de Bocskay em: Bocskay, 2017. 
os sambistas, negros e brancos, irmanados em defesa do autêntico ritmo brasileiro" (VARGENS, I997, p. 75), o ideal comunitário do projeto era unir a causa da resistência democrático-popular em torno de seu protagonista histórico mais representativo - o afro-brasileiro - e assim reconhecer a "cor" da identidade subalterna como caracteristicamente negra. Como afirma Joel Rufino dos Santos, apresentar o problema do negro como o problema do Brasil é a forma mais radical de combater o racismo, porque a configuração social do ser negro (definida pelo fenótipo escuro, pela condição social pobre, pela origem ancestral africana e pela construção social da identidade) é um lugar que pode ser ocupado inclusive pelo não negro (RUFINO, I996, p. 223).

Ao colocar a resistência negra dessa forma, como a "questão nacional" determinante, a política do Quilombo se aproximava daquela do MNU, cuja carta fundadora convocava a "todos os setores democráticos que lutam contra o desrespeito e as injustiças aos direitos humanos a engrossarem fileiras com a Comunidade Afro-Brasileira nesse ato contra o racismo" (PEREIRA, 20Io, p. I87). Como o Quilombo, a carta de princípios do MNU refutava o discurso nacionalista da assimilação racial, reivindicando no seu lugar uma reavaliação do papel negro na história do Brasil (PEREIRA, 20Io, p. I9), uma ênfase renovada na consciência e memória negra (COSTA, 2006, p. I44), uma política de militância popular-democrática e emancipatória (PEREIRA, 20Io, p. 99), e uma estratégia antirracista de frente ampla, que unificasse os interesses de raça e classe em torno de uma única pauta negro-popular (TAVARES, 2008, p. II; PEREIRA, 20IO, p. I87). O Quilombo fez uma contribuição bastante prática a essa estratégia nas festividades que organizou em I977 e I978 em homenagem aos 3.000 associados do Sindicato dos Estivadores do Cais do Porto e a um número semelhante de trabalhadores da construção civil (CANDEIA; ISNARD, I978, p. 84). Trinta anos depois, Vargens refletia sobre o caráter político dessa iniciativa como uma expressão contemporânea do modelo de luta negra, o quilombo, que era a sua inspiração:

E não era só samba e comida. Havia palestras, exibição de filmes, debates. Esse espaço você não tinha nem dentro das universidades, porque havia uma repressão. Então era um quilombo mesmo, um lugar de resistência. A coisa não foi tão elaborada conscientemente, não é? Mas, partindo das pessoas que criaram o grupo - isso a gente vê hoje, trinta e tantos anos depois -, era um movimento... (VARGENS apud CUNHA, 2009, p. 55) $)^{\text {I5 }}$.

O documento do MNU falava do Quilombo dos Palmares de modo semelhante, como a "primeira e única tentativa brasileira de estabelecer uma sociedade democrática, ou seja, livre, e em que todos - negros, índios, brancos - realizaram um grande avanço político e social. Tentativa esta que sempre esteve presente em todos os quilombos" (apud PEREIRA, 20IO, p. IOI) ${ }^{\mathrm{I} 6}$.

As interpretações do caráter social do Quilombo dos Palmares e da sua significação política já são diversas (ANDERSON, I996, p. 545-566; FUNARI, 200I),

I5 Vargens em entrevista em 2008 com o autor.

I6 Documento de encerramento da II Assembleia Nacional do MNU, realizada em 4 de novembro de I978, em

Salvador (BA). 
mas, para o movimento antirracista pós-I970, a leitura mais elaborada e de maior influência era aquela do respeitado militante e intelectual Abdias do Nascimento. Durante o exílio nos Estados Unidos entre I968 e I978, Nascimento desenvolveu o conceito do "quilombismo" como a conjugação de uma filosofia, uma prática e um projeto políticos, cujo objetivo último era a criação de um estado nacional igualitário e democrático, o estado quilombola. Em O quilombismo, o texto de I980 que reunia as dimensões desse pensamento, Nascimento prestava homenagem a Candeia e ao G. R. A. N. E. S. Quilombo como modelo exemplar do ideal quilombista quando ele sai da condição de resistência sublimada para se tornar plenamente ativo e subversivo (NASCIMENTO, I980).

Mas vale perguntar o quanto tinham em comum o Quilombo de Candeia e o quilombismo de Nascimento. Num aspecto importante os dois projetos divergem, ou seja, na perspectiva africanista de Nascimento em relação à identidade negra moderna; em O quilombismo, como observa Antônio Sérgio Guimarães, a "presença viva da Mãe África" é resgatada para a "nação Negra" contra a sua rejeição por parte das classes dominantes do Brasil, e nisso a ideia fundamental é que os quilombos constituiriam uma adaptação das tradições africanas de comunitarismo ao ambiente brasileiro (GUIMARÃES, 2006). Com certeza, Candeia e Isnard concordariam com a opinião de Nascimento de que, ao lado dos povos indígenas, os escravos foram os primeiros a "erguer as estruturas deste país chamado Brasil" (NASCIMENTO, I980, p. 253) e que "o negro está longe de ser um arrivista ou um corpo estranho: ele é o próprio corpo e alma deste país” (NASCIMENTO, I980, p. 253). Mas, para eles, era como negros, e não como africanos, que se percebia a luta dos ex-escravos na frente de um movimento amplo para reivindicar a questão nacional como um projeto democrático-popular.

Porém, as duas propostas coincidem, sim, em outros aspectos importantes: a) na visão do quilombo como um modelo de luta emancipatória de natureza racial e de classe, simultaneamente, o que implicaria numa transformação geral das estruturas social e econômica do Brasil: "A revolução quilombista é fundamentalmente antirracista, anticapitalista, antilatifundiária, anti-imperialista e antineocolonialista" (NASCIMENTO, I980, p. 277); b) na mesma compreensão do conceito de resistência - Antônio Sérgio Guimarães aponta para a virada no pensamento de Nascimento durante o exílio de I968-I978 que o levou a conciliar "os conceitos eruditos de revolta e resistência com os conceitos nativos de revolta e de quilombo, recriando assim, no plano da política de identidade, um passado heroico para o povo negro brasileiro e um futuro de luta" (GUIMARÃES, 2006, p. I63); c) no consenso no que diz respeito à relação entre a tradição da resistência e o poder criativo da cultura afro-brasileira. Num discurso proferido ao Congresso dos Estados Unidos em I980, Nascimento afirmou:

Existe outra condição da vida africana que nunca se modificou durante a história do meu povo: nossa resistência contra a opressão e nossa vitalidade e força criativas. Trouxemos conosco, desde a África, a força do nosso espírito, das nossas instituições socioeconômicas e políticas, de nossa religião, arte e cultura. É essa a essência do nosso conceito de quilombo. (NASCIMENTO, I982 apud GUIMARÃES, 2006, p. I64). 
Quando o Manifesto do Quilombo declarava "Venho com fé. Respeito mitos e tradições. Trago um canto negro. Busco a liberdade”, ele não apenas se arrogava um discurso intelectual-literário de autoafirmação negra, mas também anunciava a sua intenção de dar vida renovada à prática do samba no espaço mágico da rua, enquanto ato de performance. Para os ativistas do Quilombo, os artistas, ou seja, os compositores e intérpretes, eram os portadores autênticos da identidade afro-brasileira, por oposição aos técnicos profissionalizados, os carnavalescos (CANDEIA; ISNARD, I978, p. 90-9I). As passistas, por exemplo, eram as "que transmitem o ritmo do samba através da ginga do corpo e, principalmente mostram nos pés a música do nosso povo" (CANDEIA; ISNARD, I978, p. 36). Sabemos como era importante, para a narrativa autobiográfica de Candeia, a sua proximidade já na infância, no ambiente semirrural de Oswaldo Cruz nos anos I930, às danças, canções e práticas religiosas e profanas da cultura afro-brasileira na era da pós-escravidão, tais como o samba de roda, o samba de terreiro, o jongo, o caxambu, a capoeira e o candomblé (BUSCÁCIO, 2005, p. 58). Ao contarem a história das escolas de samba, Candeia e Isnard comunicaram a sua veneração por essas manifestações comunitárias, junto com seus correspondentes modernos - o samba de partido-alto, o samba-enredo, o samba de exaltação, e as artes culinárias, o traje e a linguagem associados a eles - como conhecimento cultural tanto quanto como prática criativa: "São tão grandes as contribuições à criatividade dadas pelos sambistas que convém lembrar que muito do que é criativo na vida humana consiste na redescoberta do que os outros descobriram antes, daí o respeito aos produtos originais" (CANDEIA; ISNARD, I978, p. 72). E por isso mesmo eles apelavam às escolas para que apoiassem esse princípio vital da criatividade cultural no sentido do ensino, da pesquisa, dos concursos e do investimento financeiro. Ao tomar a iniciativa em promover essa pauta, as atividades do próprio Quilombo, sobretudo a partir de meados de I976, incluíam ensaios e apresentações em todos os fins de semana, abrangendo uma diversidade impressionante de artes regionais, além daquelas já mencionadas - como maculelê, afoxé, maracatu, samba de lenço, samba de caboclo e lundu (CANDEIA; ISNARD, I978, p. 7).

Mas para o Quilombo, entre todas aquelas manifestações, a epítome do princípio da prática criativa negra era o samba de partido-alto. Era o partido-alto - no seu movimento responsorial entre o refrão fixo, de participação coletiva, e os versos inventados pelos solistas - que exemplificava melhor aquela interação entre, por um lado, o respeito pela tradição e a reprodução de suas formas familiares e, por outro lado, a transformação destas por via da interpretação, variação e invenção criativas - o que poderíamos denominar em outras palavras como a arte da improvisação. Num comentário gravado no volume 2 (I976) do álbum Partido em 5, a sua celebração do gênero, Candeia inaugura esse espírito de diálogo com a tradição popular: "Olha aí gente, este é o Partido em 5 novamente [...] um samba puro, samba sem poluição. Um samba que nasce do povo, de gente do povo e que vai para o povo novamente" (apud SILVA, 2008, p. I7). Felizmente, podemos ainda assistir a esse processo improvisatório em ação, dirigido pelo próprio Candeia, no documentário Partido alto (I982) de Leon Hirszman. Gravado em I976 na casa de Candeia, na sede do Quilombo e em outros locais, o filme mostra cenas onde ele explica as variações dentro da prática do 
partido-alto, e convida aos outros artistas a demonstrarem o diálogo improvisatório entre dançarinos e músicos, entre solista e coro:

Samba-de-partido-alto: em algumas formas existe uma grande semelhança com a música nordestina, com o repentista nordestino, porque o samba-de-partido-alto também é aquela forma da improvisação que vai nascendo, não só sobre os temas, o refrão, mas também sobre o ambiente, sobre um clima que vai se criando aos poucos. (HIRSZMAN, I982).

Como já vimos, a partir de meados dos anos I970 ocorriam grandes debates dentro do movimento negro organizado acerca do potencial ou não de uma contribuição cultural à causa antirracista. Enquanto os africanistas da Sinba menosprezavam a cultura afro-brasileira como algo irremediavelmente viciado e cooptado, o IPCN procurava recuperar o campo cultural como esfera de ação política, abraçando as identidades "negras" não tradicionais como aquelas inspiradas por estilos norte-americanos (ALBERTO, 20II, p. 272, 275). O acadêmico estadunidense Michael Hanchard iria alimentar o debate de novo com a publicação de Orpheus and power (I994), onde ele argumentava que as tendências supostamente "culturalistas" do movimento teriam sido um fator significativo em desviar o ativismo das formas mais politicamente eficazes de intervenção, como os boicotes, a desobediência civil ou a luta armada (HANCHARD, I994).

Mas dicotomizar a questão dessa maneira interpreta mal a relação entre as formas cultural e política do ativismo, e subestima a sua capacidade mútua de revigorar-se e galvanizar-se uma à outra. Longe de desmobilizar a luta se refugiando na celebração ou na mitificação, o exemplo de projetos tais como o Quilombo serve para demonstrar como, ao resgatarem o conteúdo histórico vivo das tradições culturais negras, estas podem transformar-se em formas de recusa capazes de intervir ideológica e materialmente no presente, e assim de transbordar para a prática política. Como observa Amilcar Araújo Pereira, a Carta Aberta fundadora do MNU apelava pela

[...] criação de "Centros de Luta" "nos bairros, nas vilas, nas prisões, nos terreiros de candomblé, nos terreiros de umbanda, nos locais de trabalho, nas escolas de samba, nas igrejas... Ou seja, havia a necessidade de se articular a luta política em "todo o lugar onde o negro vive" [...], inclusive dentro de espaços majoritariamente "culturais" (PEREIRA, 20IO, p. I70).

Muitas das reivindicações "culturalistas" da fase inicial do movimento, como a proposta de comemorar-se a morte de Zumbi em 20 de novembro como o Dia Nacional da Consciência Negra, iriam se tornar o enfoque de lutas políticas decisivas em torno da questão pendente que era o legado da escravidão e da Abolição e o lugar dos negros brasileiros no passado, no presente e no futuro do país. 


\section{SOBRE O AUTOR}

DAVID TREECE é professor titular da Cátedra Camões do Departamento de Estudos Espanhóis, Portugueses e Latino-Americanos da King's College London (KLC, Reino Unido) e membro do King's Brazil Institute.

E-mail: david.treece@kcl.ac.uk

\section{REFERÊNCIAS}

ALBERTO, Paulina L. When Rio was black: soul music, national culture, and the politics of racial comparison in I970s Brazil. Hispanic American Historical Review, v. 89, n. I, p. 3-39, 2009.

ALBERTO, Paulina L. Terms of inclusion: black intellectuals in twentieth-century Brazil. Chapel Hill: University of North Carolina Press, 20Ir.

ALBERTO, Paulina. Quando o Rio era black: soul music no Brasil dos anos 70. História: Questões \& Debates, v. 63, n. 2, jul.-dez. 20I5, p. 4I-89.

ANDERSON, Robert Nelson. The Quilombo of Palmares: a new overview of a Maroon State in seventeenthcentury brazil. Journal of Latin American Studies, n. 28, 1996, p. 545-566.

BALDWIN, James. The negro in American culture. Cross Currents, v. XI, I96..BOCSKAY, Stephen. Undesired presences: samba, improvisation, and afro-politics in I970s Brazil. Latin American Research Review, v. 52, n. I, 20I7, p. 70. Disponível em: 〈https://doi.org/Io.25222/larr.7I>.

BUSCÁCIO, Gabriela Cordeiro. A chama não se apagou: Candeia e a Gran Quilombo - movimentos negros e escolas de samba nos anos 70. Dissertação (Mestrado em História Social). Instituto de Ciências Humanas e Filosofia, Universidade Federal Fluminense, 2005.

CABRAL, Sérgio. As escolas de samba do Rio de Janeiro. Rio de Janeiro: Lumiar, I996.

CAMMETT, John W. Antonio Gramsci and the origins of Italian communism. California: Stanford University Press, I967, p.202.

CANDEIA. Luz da Inspiração Atlantic/WEA. I977.

CANDEIA \& ISNARD. Escola de samba: árvore que esqueceu a raiz. Rio de Janeiro: Lidador/SEEC, I978.

CANDEIA. Raridades, Candeia - sou mais o samba. Discobertas. DBOX-39. 20I4.

CONTINS, Márcia. Lideranças negras. Rio de Janeiro: Aeroplano, 2005.

COSTA, Sérgio. Dois Atlânticos: teoria social, anti-racismo, cosmopolitismo. Belo Horizonte: Editora UFMG, 2006.

CUNHA, Ana Cláudia da. O Quilombo de Candeia: um teto para todos os sambistas. I24 f. Dissertação (Mestrado em Bens Culturais e Projetos Sociais). Centro de Pesquisa e Documentação de História Contemporânea, CPDOC, Fundação Getúlio Vargas, 2009.

DUNN, Christopher. Black Rio. In: . Contracultura: alternative arts and social transformation in authoritarian Brazil. Chapel Hill: The University of North Carolina Press, 20I6, p.I46-74.

FERNANDES, Dmitri Cerboncini. A negra essencialização do samba. Luso-Brazilian Review, v. 5I, n. I, 20I4, p. I32-I56.

FRIAS, Lena. Black Rio: o orgulho (importado) de ser negro no Brasil. Jornal do Brasil, Caderno B, I7 jul. I976. 
FUNARI, Pedro Paulo A. Heterogeneidade e conflito na interpretação do Quilombo dos Palmares. Revista de História Regional, v. 6, n. I, 200I, p. II-38.

GONZALEZ, Lélia. O movimento negro na última década. In: GONZALEZ, Lélia; HASENBALG, Carlos. Lugar de negro. Rio de Janeiro: Marco Zero, I982.

GUIMARÃES, A. S. A. Resistência e revolta nos anos I960 - Abdias do Nascimento. Revista USP, n. 68, 2006, p. I56-I67.

HANCHARD, Michael George. Orpheus and power: The Movimento Negro of Rio de Janeiro and São Paulo, Brazil, I945-I988. Princeton, NJ: Princeton Univ. Press, I994.

HIRSZMAN, Leon (Dir.). Partido Alto. Embrafilme, I982. Disponível em: <https://www.youtube.com/ watch?v=C44D2qotCIE >. Acesso em: 9 nov 2017.

MAIO, Marcos Chor; SANTOS, Ricardo Ventura (Org.). Raça, ciência e sociedade. Rio de Janeiro: Fiocruz/ Centro Cultural Banco do Brasil, I996.

MCCANN, Bryan. Black Pau: uncovering the history of Brazilian soul. Journal of Popular Music Studies, n. 14,2002 , p. 33-62.

MONTE, Maria Lucia. O erudito e o que é popular, ou Escolas de Samba: a estética negra de um espetáculo de massa. Revista USP, n. 32, I996-I997, p. 8-25.

MOTTA FARIA, Guilherme José. As transformações temáticas nos desfiles das escolas de samba do Rio de Janeiro e os debates sobre autenticidade versus modernidade (I960-2000). Anais do XXVII Simpósio Nacional de História ANPUH, 2013.

MOURA, Roberto M. No princípio, era a roda: um estudo sobre samba, partido-alto e outros pagodes. Rio de Janeiro: Rocco, 2004.

NAPOLITANO, Marcos. Seguindo a canção - engajamento político e indústria cultural na MPB (I959-I969). São Paulo: Annablume/Fapesp, 200I.

NASCIMENTO, Abdias do. O quilombismo: documentos de uma militância pan-africanista. Petrópolis: Vozes, I980. Disponível em: 〈http://www.abdias.com.br/movimento_negro/quilombismo.htm〉. Acesso em: 9 nov. 2017.

NEWLANDS, Lilian. Velha Guarda da Portela: "Falam de mim”. In: VARGENS, João Baptista M. (Org.). Notas musicais cariocas. Petrópolis: Vozes, I986, p. III-I34.

O NEGRO da senzala ao soul: Um documentário da TV Cultura. Departamento de Jornalismo da TV Cultura de São Paulo, I5/7/I977. Disponível em: 〈https://www.youtube.com/watch?v=5AVPrXwxhIA >. Acesso em: 9 nov. 2017.

OLIVEIRA, Iris Agatha de. Black soul e "samba de raiz": convergências e divergências do Movimento Negro no Rio de Janeiro, I975-I985. 2014. 206 f. Dissertação (Mestrado em Memória Social). Programa de PósGraduação em Memória Social, Universidade Federal do Estado do Rio de Janeiro - Unirio, 20I4, p.I52. PEREIRA, Amilcar Araújo. "O Mundo Negro": a constituição do movimento negro contemporâneo no Brasil (I970-I995). 20I0. 268 f. Tese (Doutorado em História). Instituto de Ciências Humanas e Filosofia, Universidade Federal Fluminense, 2010.

RANULPHO, Waldinar. Escola de Samba Quilombos para salvar o samba. Última Hora, 7 nov. I976.

REIS, Aloysio. A libertação é um grito SOUL. Última Hora, 27 maio I976, citado no Boletim do IPCN, jul. I976, apud ALBERTO, Paulina. Quando o Rio era black: soul music no Brasil dos anos 70. História: Questões er Debates, v. 63, n.2, jul.-dez. 20I5, p. 85.

RODRIGUES, Ana Maria. Samba negro, espoliação branca. São Paulo: Hucitec, I984, p. I09 apud FERNANDES, Dmitri Cerboncini. A negra essencialização do samba. Luso-Brazilian Review, v. 5I, n. I, 20I4, p. I32-I56.

RODRIGUES DA SILVA, Carlos Benedito. “Black soul”: aglutinação espontânea ou identidade étnica. 
Uma contribuição ao estudo das manifestações culturais no meio negro. Ciências Sociais Hoje, v. 2, I983, p. 260-26I.

RUFINO DOS SANTOS, Joel. O negro como lugar. In: MAIO, Marcos Chor; SANTOS, Ricardo Ventura (Org.). Raça, ciência e sociedade. Rio de Janeiro: Fiocruz/Centro Cultural Banco do Brasil, I996.

SANTOS, Sales Augusto dos. A metamorfose de militantes negros em negros intelectuais. Revista Mosaico, v. 3, n. 5, 20II, p. IO2-I25.

SEBADELHE, Zé Octávio; LIMA PEIXOTO, Luiz Felipe de. 1976 - Movimento Black Rio. Rio de Janeiro: José Olympio, 2016.

SEPÚLVEDA DOS SANTOS, Myrian. Mangueira e Império: a carnavalização do poder pelas escolas de samba. In: ZALUAR, Alba; ALVITO, Marcos (Org.). Um século de favela. Rio de Janeiro: Fundação Getúlio Vargas, I998.

SILVA, Francisco Ernesto da. Candeia e a Escola de Samba Quilombo: a crítica ao processo de branqueamento das manifestações culturais afro-brasileiras. Trechos da Monografia de Francisco Ernesto da Silva para o Curso de História da Universidade Guarulhos - UnG, 2008. Disponível em: <http://www. academiadosamba.com.br/monografias/franciscoernesto.pdf $>\mathrm{S}$

SWANN, Carlos. Samba é vendido ao turismo oficial. O Globo, 26 de novembro de I975.

TAVARES, Julio Cesar de. Diásporas africanas na América do Sul: uma ponte sobre o Atlântico. Brasília: Fundação Alexandre de Gusmão, 2008.

THAYER, Allen. Black Rio: Brazilian soul and DJ culture's lost chapter. Waxpoetics, n. I6, abril-maio 2006, p. 9I.

TINHORÃO, José Ramos. Música popular: um tema em debate. Rio de Janeiro: Saga, I966.

. Pequena história da música popular. São Paulo: Círculo do Livro, I975.

TOSTA DIAS, Marcia. Os donos da voz: indústria fonográfica brasileira e mundialização da cultura. São Paulo: Boitempo, 2000.

TROTTA, Felipe; CASTRO, João Paulo M. A construção da ideia de tradição no samba. Cadernos do Colóquio (UniRio), v. 3, n. I, 200I, p. 62-74.

VARGENS, João Baptista M. (I987). Candeia: luz da inspiração. 3. ed. Rio de Janeiro: Funarte, I997.

VIANNA, Hermano. O mundo funk carioca. Rio de Janeiro: Jorge Zahar, I988.

VIVEIROS DE CASTRO, Maria Laura. O rito e o tempo: ensaios sobre o carnaval. Rio de Janeiro: Civilização Brasileira, I999.

VIVEIROS DE CASTRO CAVALCANTI, Maria Laura. Carnaval carioca: dos bastidores ao desfile. Rio de Janeiro: EdUFRJ, 2006. 